\title{
Corruption and international trade: a comprehensive analysis with gravity
}

\author{
Salvador Gil-Pareja, Rafael Llorca-Vivero and \\ José Antonio Martínez-Serrano \\ Universitat de Valencia and INTECO Research Group, Valencia, Spain
}

Corruption and international trade

Received 17 May 2018 Revised 28 November 2018 Accepted 18February 2019

\begin{abstract}
Purpose - The purpose of this paper is to analyze the impact of corruption on trade.

Design/methodology/approach - The authors estimate gravity equations with the last econometric advances on a wide sample of countries and years using three different measures of corruption. Two of them belong to the so-called perception-based indexes and the third is derived from a structural model that takes into account the causes and indicators of corruption across countries.

Findings - A negative effect of corruption on trade appears with perceptions, but it is not widespread. However, the authors find sensible evidence of the "grease the wheels" view with the structural index if low and middle income countries are implicated. Additionally, when using this measure, differences in corruption levels negatively impact trade. Both results are in line with expectations.
\end{abstract}

Originality/value - Moreover, membership in regional trade agreements does not seem to significantly alter these results.

Keywords International trade, Corruption, Gravity equation, Income level,

Regional trade agreements

Paper type Research paper

\section{Introduction}

Corruption in the public sector is probably one of the main elements of failures in governance (Acemoglu and Verdier, 2000) which directly affects institutional quality and, thereby, the well-being of the society. The World Bank and the International Monetary Fund share the opinion that corruption, as one of the determinants of the poor functioning of institutions, is a great obstacle to economic and social development. Diverse authors show how a higher degree of corruption negatively affects economic growth (Mauro, 1995), slows down the flow of foreign direct investment (Wei, 2000) or distorts tax revenues (Mauro, 1998). The uncertainty in the decision making by economic agents, the poor law enforcement affecting business agreements because of the insecurity around the legal solution to disputes or the inefficient allocation of resources are the most common arguments that are behind this adverse impact.

(C) Salvador Gil-Pareja, Rafael Llorca-Vivero and José Antonio Martínez-Serrano. Published in Applied Economic Analysis. Published by Emerald Publishing Limited. This article is published under the Creative Commons Attribution (CC BY 4.0) licence. Anyone may reproduce, distribute, translate and create derivative works of this article (for both commercial and non-commercial purposes), subject to full attribution to the original publication and authors. The full terms of this licence may be seen at http://creativecommons.org/licences/by/4.0/legalcode

JEL classification - F14, F15

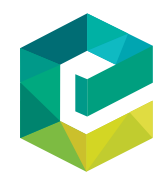

Applied Economic Analysis Vol. 27 No. 79,2019 pp. $3-20$ Emerald Publishing Limited $2632-7627$ 
AEA

27,79

However, other authors present corruption as a factor that, under certain circumstances, may facilitate economic exchanges, thus improving efficiency [see, for example, Egger and Winner (2005), for foreign direct investment or Dreher and Gassebner (2013) for firm entry]. The reason is that, in economic systems with extensive and complex regulations as well as weak institutions, bribes can help companies to avoid formal regulatory barriers. That is, corruption would serve as a mechanism for deregulation. This is the "grease the wheels" hypothesis. In this line of research, Méon and Weill (2010) find, using a sample of 69 developed and developing countries, that this hypothesis is accomplished in its weak and strong forms: corruption has a less detrimental effect on efficiency in countries with a low degree of effectiveness of their institutions and a positive effect in countries with especially ineffective institutions. Therefore, there are reasons to believe that the real impact of corruption will depend on the conditions under which it operates, although on the set of empirical contributions the negative impact usually predominates over the positive one.

The relationship between corruption and international trade is a less explored area. The motives for expecting that the effect of corruption on international trade flows is favorable or detrimental are similar to those outlined above. On the one hand, the improper functioning of the legal framework can hinder the effectiveness of the contracts, a fact that discourages international transactions by increasing the cost of exporting (Anderson and Marcouiller, 2002). So, corruption would have an impact that is similar to the establishment of a tariff. On the other hand, if tariff and/or non-tariff barriers (for instance, complex administrative formalities) are high, bribes could facilitate trade since they would help to overcome these obstacles.

The specialized literature shows that the positive effect of corruption on trade (evasion) will surpass the negative effect (extortion) in those markets in which tariffs are relatively high (Dutt and Traca, 2010). A corollary is that corruption favors international trade in those cases in which destination markets present barriers that exceed a certain threshold. The empirical research finds a negative effect of corruption on international trade. This is the case of Levchenko (2007), focusing on institutional quality, Pomfret and Sourdin (2010), showing that direct trade costs increase with corruption, Zelekha and Sharabi (2012), discussing the case of Israel and Masila and Sigue (2010), on a sample of 47 African countries. Nevertheless, Voraveeravong (2013) estimates a positive effect for ASEAN countries whereas Akbarian and Shirazi (2012) find an inverted U relationship between corruption and trade for a sample of countries of the Middle East and Latin America. This implies that, for such countries, an increase of corruption from relatively low levels would increase trade while from relatively high levels would reduce it.

Additionally, the phenomenon of corruption presents different aspects that can influence the degree in which it will affect international trade. This fact is highlighted by Thede and Gustafson (2009). These factors come from the seriousness of such conduct (if the corruption is severe it can limit or even prevent transactions), its prevalence (which increases the costs of looking for an honest partner), its function (obstruction of market competition) or its predictability (the more predictable is the lower costs implies). Other authors also highlight several factors that should be taken into account. For instance, De Jong and Bogmans (2011) outline the importance to determine if countries act as exporters or importers. Horsewood and Voicu (2012) argue that differences in the ethical standards of countries would also negatively affect trade and Knack and Azfar (2003) pose the problems of sample selection and bias resulting from those databases that incorporate a small number of countries.

Our aim is to shed light on the relationship between corruption and international trade. To this end, we have made use of three different measures of corruption. Two of them belong to the so called perception-based indexes. The other [from Deher et al. (2007)] is the 
result of a structural modelling which takes into account the causes and indicators of corruption across countries. This last index, constructed with an economic basis, tries to overcome the shortcomings of the indexes based on perceptions.

We estimate gravity equations on a large sample of countries and years controlling for a wide set of potential biases: unobserved bilateral heterogeneity, multilateral resistance changes over time, heteroskedastic residuals and the existence of zero trade flows. Until very recently, there was not possible to account for all these sources of biases simultaneously in large samples because of convergence problems in the estimations.

Corruption and international trade

However, Larch et al. (2017) provide a routine to deal with high dimensional fixed effects. The contribution of this paper is twofold. The first is to estimate the impact of corruption on international trade accounting simultaneously for the four potential sources of bias. The second is the use, for the first time, of a corruption variable with a solid economic basis.

To preview our results, we find that, once the aforementioned potential biases are controlled for, the impact differs from the perception-based indexes to the structural index. This result makes sense given that the structural index corrects for measurement errors of the other indexes. In particular, when perception-based indexes are used we find a negative effect of corruption on trade but this result is far from being generalized. However, using the structural index, estimations suggest sensible evidence for the "grease the wheels" hypothesis. That is, corruption positively impacts trade when low and middle income countries (which are those with weak institutions and high regulations) are implicated. Moreover, when controlling for RTA membership, we do not find any significant difference in previous conclusions.

The rest of the paper is organized as follows. In Section 2, we describe the methodology. Section 3 offers the data sources. Section 4 presents the results and Section 5 concludes.

\section{Methodology}

The vast majority of the papers analyzing the impact of corruption on trade use the gravity model, which name proceeds from its analogy to the Newtonian physics. The basic version of the gravity equation relates bilateral trade flows positively to the economic size of countries and negatively with the distance between them. Nevertheless, it has been usual the inclusion of other factors affecting trade barriers such as sharing a border, a common language or be part of the same regional trade agreement[1]. In particular, our benchmark augmented gravity equation takes the following form:

$$
\begin{aligned}
\ln _{\mathrm{ijt}}= & \beta_{0}+\beta_{1} \operatorname{lnY}_{\mathrm{it}}+\beta_{2} \ln _{\mathrm{jt}}+\beta_{3} \text { lndist }_{\mathrm{ij}}+\beta_{4} \text { border }_{\mathrm{ij}}+\beta_{5} \text { comlang }_{\mathrm{ij}}+\beta_{6} \text { colony }_{\mathrm{ij}} \\
& +\beta_{7} \text { comctry }_{\mathrm{ij}}+\beta_{8} \text { island }_{\mathrm{ij}}+\beta_{9} \text { landlocked }_{\mathrm{ij}}+\beta_{10} \text { religion }_{\mathrm{ij}}+\beta_{11} \text { RTA }_{\mathrm{ijt}} \\
& +\beta_{12} \mathrm{CU}_{\mathrm{ijt}}+\beta_{13} \text { corrup }_{\mathrm{ijt}}+\beta_{14} \text { difcorrup }_{\mathrm{ijt}}+\lambda_{\mathrm{t}}+\mathrm{u}_{\mathrm{ijt}}
\end{aligned}
$$

where $\ln$ denotes logarithm, $\mathrm{i}$ and $\mathrm{j}$ denote trading partners, $t$ is time, and the variables are defined as follows: $\mathrm{X}_{\mathrm{ij}}$ are the bilateral export flows from $\mathrm{i}$ to $\mathrm{j}, \mathrm{Y}$ denotes gross domestic product (GDP), dist is the distance between $\mathrm{i}$ and $\mathrm{j}$, contiguity is a dummy variable which is unity if $\mathrm{i}$ and $\mathrm{j}$ share a land border, comlang is a dummy variable which is unity if $\mathrm{i}$ and $\mathrm{j}$ have a common language, colony is a binary variable which is unity if $\mathrm{i}$ ever colonized $\mathrm{j}$ or vice versa, comctry is a binary variable which is unity if $i$ and $j$ were part of a same country in the past, island is a dummy variable which is unity if there are island nations in the pair, landlocked is a dummy variable which is unity if there are landlocked countries in the country-pair, religion is an index of common religion[2], RTA is a binary variable which is 
AEA

27,79

unity if $\mathrm{i}$ and $\mathrm{j}$ belong to the same Regional Trade Agreement, $\mathrm{CU}$ is a binary variable which is unity if $\mathrm{i}$ and $\mathrm{j}$ belong to the same Currency Union, corrup is an index of corruption of the country pair (our variable of interest), difcorrupt is a measure of the difference in the level of corruption in the country-pair, $\lambda_{\mathrm{t}}$ are time dummies and $\mathrm{u}_{\mathrm{ijt}}$ is the standard classical error term.

Originally, gravity equations were estimated by pooled Ordinary Least Squares. However, since the 2000s, several influential papers highlighted some relevant points that were necessary to take into account in the estimation of gravity equations to avoid misspecification issues. First, Egger (2002) outlines the necessity to control for country-pair specific factors influencing their mutual trade but which are invariant over time (unobserved bilateral heterogeneity). The inclusion of country-pair fixed effects (CPFE) in panel data set accounts for this. Additionally, country-pair fixed effects adequately control for the main sources of endogeneity (Baier and Berstrand, 2007 or Gil-Pareja et al., 2017). Obviously, the effects of country-pair dyadic variables (distance, common language, etc.) are captured by these bilateral fixed effects.

Second, Anderson and van Wincoop (2003) outline the necessity to account for relative trade barriers by including in the estimation "multilateral resistance" terms. This leads to the theoretically based gravity equation. To take into account multilateral resistance terms in cross-section samples, it is necessary the inclusion of country fixed effects, both when countries act as exporters and when they act as importers. However, as multilateral resistance terms may vary over time in panel data models, researchers [Klein and Shambaugh (2006), Baier and Bergstrand (2007), Gil-Pareja et al. (2008a, 2008b)] include country-year fixed effects (CYFE).

Third, the existence of a high volume of zero trade flows in large samples[3] (Helpman, Melitz and Rubinstein (2008) as well as econometric problems resulting from heteroskedastic residuals (Santos Silva and Tenreyro, 2006, 2010) are further elements to be considered. The proposal of these last authors to control for zeros in the dependent variable and heteroskedastic residuals is to run a non-linear Poisson estimator (Poisson pseudomaximum likelihood estimation - PPML). This is the most accepted methodology to estimate gravity equations.

Therefore, taking into account the above considerations, to obtain unbiased estimations, the correct way to proceed is to use a PPML estimator with CYFE and CPFE and this will be our preferred specification:

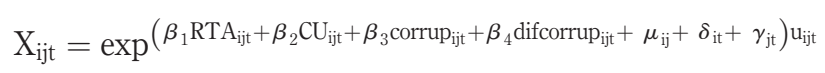

where $\mu_{\mathrm{ij}}$ are CPFE and $\delta_{\mathrm{it}}$ and $\gamma_{\mathrm{jt}}$ are exporter-year an importer-year fixed effects.

We have incorporated into the regression two pair-specific corruption variables[4]. The first (corrup $\mathrm{ijt}_{\mathrm{ij}}$ ) is the geometric mean of the values of the respective corruption variables for the exporter and the importer[5]. This is going to give us an average of the corruption level in which the corresponding pair of countries are involved. We use a geometric mean because it is more appropriate for the characteristics of the data at hand especially with CPI and CCI because these indexes establish a ranking of countries in corruption levels. Additionally, the geometric mean gives less weight to extreme values in data.

The second one (difcorrup $\mathrm{ijt}_{\mathrm{j}}$ ) is the absolute value of the difference between the corruption indexes for the exporter and the importer. This provides us the "distance" in the corruption levels between the pair of countries. In this sense, Horsewood and Voicu (2012) have found that trade is reduced as far as the differences in this institutional characteristic widens. We will test this result with our sample and different measures of corruption.[6] 
Additionally, in our regressions, we will consider two factors that may influence the relationship between corruption and trade: the income level of countries and membership in regional trade agreements. On the one hand, the institutional environment could determine the real impact of corrupt behaviour on economic variables. Stronger institutions fight more efficiently against corruption and the richest countries have better institutions. To account for this, we will run regressions taking into consideration the income level of countries. On the other hand, one of the most striking events in the past two decades at the international level has been the massive proliferation of regional trade agreements all over the world, regardless of the degree of development. Countries belonging to a RTA have more transparent commercial relationships and a higher level of certainty and both elements may be able to reduce the negative effect of corruption[7]. Therefore, we will also consider the eventual membership of the pair of countries to an RTA.

\section{Data}

The export flows from country $\mathrm{i}$ to country $\mathrm{j}$ come from the "Direction of Trade (DoT)" dataset, which is constructed by the International Monetary Fund (IMF). The data comprise bilateral merchandise trade between 139 countries and territories (see Table A1 in the Appendix) over the period 1975-2012. GDP data are from the World Development Indicators (World Bank). Geographical coordinates for the construction of great circle distances and the dummies for physically contiguous neighbours, common language, common colonizer, common country, the existence of islands in the pair, the existence of landlocked countries in the pair and the index of common religion are from the CIA's World Factbook. The indicators of Regional Trade Agreements (RTA) have been built using data from the World Trade Organization, the Preferential Trade Agreements Database (The Faculty of Law at McGill University) and the website http:/ec.europa.eu/trade/issues/bilateral/index_en.htm. The indicators of currency unions are taken from Reinhart and Rogoff (2002), CIA's World

\begin{tabular}{llrrrcc}
\hline Variable & Sample & \multicolumn{1}{c}{ Obs. } & \multicolumn{1}{c}{ Mean } & SD & Minimum & Maximum \\
\hline CPI & Total & 262,988 & 4.422 & 2.307 & 0.4 & 10 \\
& High Income & 101,192 & 6.714 & 1.995 & 1.7 & 10 \\
& Middle Income & 124,822 & 3.154 & 0.919 & 0.69 & 6.45 \\
\multirow{5}{*}{ CCI } & Low Income & 36,974 & 2.432 & 0.581 & 0.4 & 5.3 \\
& Total & 270,216 & -0.026 & 1.034 & -2.06 & 2.59 \\
& High Income & 91,462 & 1.090 & 0.924 & -1.71 & 2.59 \\
& Middle Income & 128,158 & -0.497 & 0.454 & -1.52 & 0.86 \\
SCI & Low Income & 50,596 & -0.850 & 0.395 & -2.06 & 0.65 \\
& Total & 44,202 & 0.037 & 0.223 & -0.9047 & 0.3453 \\
& High Income & 16,263 & -0.181 & 0.201 & -0.9047 & 0.2575 \\
& Middle Income & 21,823 & 0.149 & 0.111 & -0.4723 & 0.334 \\
EXP_INT & Low Income & 6,116 & 0.217 & 0.067 & 0.971 & 0.345 \\
& Total & 300,828 & $0.21 \%$ & 0.012 & 0 & $91.04 \%$ \\
& High Income & 109,418 & $0.28 \%$ & 0.011 & 0 & $91.04 \%$ \\
& Middle Income & 139,259 & $0.20 \%$ & 0.011 & 0 & $47.24 \%$ \\
& Low Income & 52,151 & $0.13 \%$ & 0.009 & 0 & $37.74 \%$
\end{tabular}

Notes: For CPI and SCI, a higher value implies less corruption and for SCI the contrary occurs. EXP_INT: Export intensity, constructed for the sample 1975-2012. The mean of this variable is calculated taking into account also the zero values. Sample period: 1995-2012 for CPI; 1996, 1998, 2000 and 2002 to 2012 for CCI and 1978, 1983, 1988 and 1994 for SCI

Source: Self made
Corruption and international trade

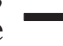


AEA

27,79

Factbook, and Masson and Pattillo (2005). The sample includes around 200 regional trade agreements (plurilateral and bilateral) and 17 currency unions.

To construct our variable of interest we have resorted to three different sources. The first one is the Corruption Perception Index (CPI) from Transparency International. This index is built since 1995 and goes from 0 (a highly corrupt country) to 10 (a very clean country) although the scale has changed in last years from 0 to 100[8]. As defined in its website, this index ranks countries depending on perceptions about corruption in the public sector. That is, it is based on values given by people with founded opinions as analyst, businesspeople or experts in the area. Transparency International considers all types of corruption: that which is exercised by high levels of governments (grand corruption), by low and mid-levels (petty corruption) or by political decision makers (political corruption). Nowadays the index is available for most of countries in the world but at the outset there were only 41 countries ranked.

The second measure of corruption is the Control of Corruption Index $(\mathrm{CCI})$ which is elaborated in the context of the project Worldwide Governance Indicators from the World Bank. The definition of corruption is quite similar as the previous one, that is, what this source tries to measure is the perception about "the extent to which public power is exercised for private gain”. It also considers all forms of corruption. It combines data from a set of different sources (for instance, Afrobarometer, Business Enterprise Environment Survey, Freedom House, Global Integrity Index, Institutional Profiles Database, among much others) and, as such, it is based on the views of informed people and public and private organizations. The range of values goes from -2.5 (very bad governance) to +2.5 (very good governance) for around 200 countries and territories and for the years 1996, 1998, 2000 and 2002 onwards.

Finally, we resort to the (what we call) Structural Corruption Index (SCI) by Dreher et al. (2007). This index has been built trying to overcome the shortcomings that, according to some authors, present the perception-based indexes. On the one hand, these indexes are not connected with the causes of corruption and, consequently, may not be a reflection of actual corruption (see, for instance, Mocan, 2008). On the other hand, Weber Abramo (2008) shows that perceptions about corruption in poor countries are a bad indicator of the effect of this phenomenon on institutions, and that these perceptions are closely related to opinions about other countries' aspects (i.e. violence). These facts invalidate, in the author's opinion, the reliance of these indexes as a measure of the real incidence of corruption. Finally, Razafindrakoto and Rouboud (2010), through direct surveys on experts' perceptions on eight African countries, conclude that these indexes are erroneous, also finding an "ideological bias".

The SCI considers corruption as a latent variable connected to its causes (rule of law, school enrollment, latitude, legal German origin and age of democracy) and indicators (consumption of cement, private credit, GDP per capita and capital restrictions). Therefore, the respective values are obtained based on more objective factors than opinions, which are not really connected with reality as above explained. Perceptions have inertia and are slow moving over time even in the event of important social changes in the respective countries. More importantly, as pointed out by Dreher et al. (2007), the SCI gives (in addition to an ordinal ranking of corruption across countries as CPI and CCI do) a more reliable measure of "distance" between countries in the corruption index.

The SCI index is constructed for around 100 countries for the periods 1976-1980, 19811985, 1986-1990 and 1991-1997. In our panel data sample, we have decided to assign the respective value to the year that is in the middle of each period, that is, we have data for the years 1978, 1983, 1988 and 1994. Contrary to what occurs with the other two indexes (CPI 
and $\mathrm{CCI}$ ) higher values in this case imply worse performance. For instance, for the period 1991-1997, the least corrupt country (Switzerland) has a value of -0.9047 , whereas the most corrupt country (Guinea-Bissau) presents a value of 0.3424 .

In Table I, we present descriptive statistics for these three indexes. Mean values of the respective indexes reflect a world bias to corrupt behavior[9], observing a higher relative dispersion for the CCI. One important point is the relationship between the income level and the degree of corruption of a country. Therefore, we have divided the sample into high income, middle income and low income countries following The World Bank data source[10]. For all indexes higher income levels clearly implies, on average, lower corrupt perceptions (in the case of CPI and CCI) or lower corrupt estimations (in the case of SCI). This is reflected in the mean values of each cohort as well as in the respective minimum and maximum values. Given that our interest is on trade, we have also calculated the export intensity by each income interval. Richer countries are more export oriented on average. Therefore, as the level of income increases countries are, in general, less corrupt and more export oriented.

The corruption variables used in the regressions are the geometric means of the respective corrupt indexes for the pair of countries that trade, that is, the square root of the bilateral product of the corresponding values. Then, we have to avoid negative or zero values in the CCI and SCI variables. To this end, we have made a very simple transformation. We have just summed 2.1 to all CCI values and 0.91 to all SCI values. This ensures positive values in both cases without altering the essence of the indicators. Additionally, once the geometric mean has been calculated, we have changed the sign of the variable for the CPI and CCI measures to make direct comparison of the estimated parameters with the SCI. That is, for the three cases, a negative parameter estimated implies an adverse impact of corruption on bilateral trade flows and the contrary occurs if the estimated parameter is positive.

In Table II, we present the descriptive statistics for the selected measures of corruption that are used in the regressions. One relevant aspect in international trade is the proliferation of RTAs over the last two decades. Then, we have also provided in the table the median value (which is quite close to the mean) to take it as a reference to see whether there is any statistical relationship between the level of corruption in the pair of countries and the fact that they are partners in a RTA. As shown, RTAs are clearly more prevalent between countries with a lower level (below median) of joint corruption[11]. This is

\begin{tabular}{lcrrccc}
\hline Variable & Obs. & Mean & Median & SD & Minimum & Maximum \\
\hline CPI $_{\mathrm{ij}}$ & 219,980 & -4.065 & -3.776 & 1.510 & -10 & -0.4 \\
$\mathrm{CCI}_{\mathrm{ij}}$ & 269,942 & -1.954 & -1.833 & 0.696 & -4.69 & -0.04 \\
$\mathrm{SCI}_{\mathrm{ij}}$ & 25,940 & 0.931 & 0.965 & 0.195 & 0.005 & 1.255
\end{tabular}

Percentage of pairs with RTA

Variable Below median

$\begin{array}{lrr}\mathrm{CPI}_{\mathrm{ij}} & 21.67 \% & 8.97 \% \\ \mathrm{CCI}_{\mathrm{ij}} & 17.27 \% & 8.63 \% \\ \mathrm{SCl}_{\mathrm{ij}} & 7.76 \% & 4.92 \%\end{array}$

Note: For the three indexes, a higher value of the variable implies more corruption, Sample period: 19952012 for CPI; 1996, 1998, 2000 and 2002 to 2012 for CCI and 1978, 1983, 1988 and 1994 for SCI

Source: Self made

Corruption and international trade

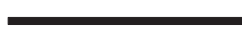


AEA 27,79

10

especially true for perception-based indexes, suggesting that countries have the tendency to form a trade agreement with partners that are perceived as less corrupt.

\section{Results}

The results for the estimations of the naive gravity equation [equation (1)] for the three measures of corruption considered are in the first column of Tables III, IV and V. As usual, the gravity equation works well explaining around 70 per cent of variation in bilateral trade flows in the three estimations. As expected, trade flows increase with countries' incomes and decrease with distance. The rest of variables of the augmented gravity equation present, in general, sensible and significant coefficients with minor exceptions depending on the sample[12]. In particular, membership in a regional trade agreement or a currency union positively affect trade, although for the sample used for CPI the coefficient corresponding to currency unions is not significant. Focusing on our variable of interest, we find that for the three selected measures corruption is detrimental for international trade, being the respective estimated coefficients significant at 1 per cent level. This is the most common result found in the literature, as already mentioned.

Taking the last year of the three samples as a reference (2012 for CPI and CCI and 1994 for SCI) and the maximum and minimum values for the average level of corruption in the pair, the estimations imply (ceteris paribus), a trade loss of around 66 per cent for the pair of countries showing a higher mean in the particular year considered with respect to the pair of countries with the lower mean for CPI[13] and CCI and around 79 per cent for SCI. Focusing

\begin{tabular}{|c|c|c|c|c|}
\hline Variables & $\begin{array}{c}(1) \\
\text { Pooled OLS }\end{array}$ & $\begin{array}{c}(2) \\
\text { Fixed Effects }\end{array}$ & $\begin{array}{c}(3) \\
\text { OLS CYFE and CPFE }\end{array}$ & $\begin{array}{c}(4) \\
\text { PPML CYFE and CPFE }\end{array}$ \\
\hline $\ln Y_{i}$ & $1.154(0.008)^{* * * *}$ & $0.495(0.013)^{* * * * *}$ & - & - \\
\hline $\ln Y_{i}$ & 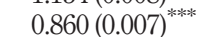 & $0.727(0.013)^{* * * *}$ & - & _- \\
\hline lndist & $-0.947(0.024)^{* * * *}$ & - & - & - \\
\hline border & $1.148(0.097)^{\text {***** }}$ & - & - & - \\
\hline contiguity & $0.872(0.046)^{\text {***** }}$ & - & _- & _- \\
\hline colony & $0.436(0.094)^{* * * *}$ & - & - & - \\
\hline comctry & $2.526(0.110)^{* * * *}$ & - & - & - \\
\hline island & $0.188(0.123)$ & - & _- & _- \\
\hline landlocked & $-0.492(0.032)^{* * * *}$ & - & - & - \\
\hline religion & $-0.171(0.056)^{* * * *}$ & - & - & - \\
\hline RTA & $0.572(0.044)^{* * * *}$ & $0.203(0.016)^{* * * *}$ & $0.130(0.017)^{* * * *}$ & $-0.017(0.037)$ \\
\hline $\mathrm{CU}$ & $0.034(0.094)$ & $0.027(0.037)$ & $0.219(0.041)^{* * * *}$ & $0.022(0.030)$ \\
\hline $\mathrm{CPI}_{\mathrm{ij}}$ & $-0.140(0.011)^{* * * *}$ & $-0.166(0.008)^{* * *}$ & $-0.279(0.043)^{* * * *}$ & $-0.019(0.063)$ \\
\hline $\mathrm{CP}_{\mathrm{i}}-\mathrm{CP}_{\mathrm{j}}$ & $-0.006(0.007)$ & $0.004(0.005)$ & $0.023(0.008)^{* * * *}$ & $0.005(0.009)$ \\
\hline Time dummies & Yes & Yes & No & No \\
\hline CPFE & No & Yes & Yes & Yes \\
\hline CYFE & No & No & Yes & Yes \\
\hline$R^{2}$ & 0.71 & 0.26 & 0.33 & 0.99 \\
\hline Observations & 153,902 & 153,902 & 161,956 & 185,529 \\
\hline
\end{tabular}

Table III.

Estimations of the impact of corruption on trade with the corruption perception index
Notes: Sample period: 1995-2012. Dependent variable: log of bilateral exports for Columns (1) to (3) and bilateral exports in levels for Column (4). Robust standard errors (clustered by country-pairs) are in parentheses. "significant at $10 \%$; ${ }^{* *}$ significant at $5 \%,{ }^{* * * *}$ significant at $1 \%$. OLS: Ordinary Least Squares. CYFE: Country-Year Fixed Effects. CPFE: Country-Pair Fixed Effects. PPML: Poisson Pseudo-Maximum Likelihood. CPI: Corruption Perception Index. The Hausman test result for random effects vs fixed effects is $2779.53(0.00)$

Source: Self made 


\begin{tabular}{|c|c|c|c|c|c|}
\hline Variables & $\begin{array}{c}(1) \\
\text { Pooled OLS }\end{array}$ & $\begin{array}{c}(2) \\
\text { Fixed effects }\end{array}$ & $\begin{array}{c}\text { (3) } \\
\text { OLS CYFE and CPFE }\end{array}$ & $\begin{array}{c}(4) \\
\text { PPML CYFE and CPFE }\end{array}$ & international \\
\hline $\ln Y_{i}$ & $1.129(0.007)^{* * * *}$ & $0.455(0.013)^{* * * *}$ & - & - & \\
\hline $\ln Y_{j}$ & $0.846(0.007)^{* * * *}$ & $0.677(0.013)^{* * * *}$ & - & - & \\
\hline lndist & $-0.964(0.023)^{* * *}$ & - & - & - & \\
\hline contiguity & $1.176(0.093) * * *$ & - & - & - & \\
\hline comlang & $0.831(0.044) * * *$ & - & - & - & 11 \\
\hline colony & $0.609(0.096) * * * *$ & - & - & - & \\
\hline comctry & $2.564(0.112)^{* * * *}$ & - & - & - & \\
\hline island & $0.196(0.121)$ & - & - & - & \\
\hline landlocked & $-0.522(0.031)^{* * * *}$ & - & - & - & \\
\hline religion & $-0.109(0.056)^{*}$ & - & - & - & \\
\hline RTA & $0.614(0.042)^{* * * *}$ & $0.202(0.016) * * *$ & $0.183(0.018) * * * *$ & $0.004(0.031)$ & \\
\hline CU & $0.182 *(0.106)$ & $0.019(0.046)$ & $0.252(0.048)$ & $0.017(0.030)$ & \\
\hline $\mathrm{CCI}_{\mathrm{ij}}$ & $-0.276(0.022)^{* * * *}$ & $-0.237(0.018) * * * *$ & $-0.491(0.094)^{* * * *}$ & $-0.522(0.207)$ ** & \\
\hline $\mathrm{CC}_{\mathrm{i}}-\mathrm{CC}_{\mathrm{j}}$ & $-0.028(0.015)^{*}$ & $-0.003(0.011)$ & $-0.021(0.017)$ & $0.036(0.022)$ & \\
\hline Time dummies & Yes & Yes & No & No & \\
\hline CPFE & No & Yes & Yes & Yes & \\
\hline CYFE & No & No & Yes & Yes & \\
\hline$R^{2}$ & 0.70 & 0.24 & 0.33 & 0.99 & \\
\hline Observations & 169,225 & 169,225 & 178,768 & 221,068 & \\
\hline \multicolumn{5}{|c|}{$\begin{array}{l}\text { Notes: Sample period: } 1996,1998,2000 \text { and } 2002 \text { to } 2012 \text {. Dependent variable: log of bilateral exports for } \\
\text { Column (1) to (3) and bilateral exports in levels for Column (4). Robust standard errors (clustered by } \\
\text { country-pairs) are in parentheses. }{ }^{*} \text { significant at } 10 \% \text {; }{ }^{*} \text { significant at } 5 \% \text {, }{ }^{* * * *} \text { significant at } 1 \% \text {. OLS: } \\
\text { Ordinary Least Squares. CYFE: Country-Year Fixed Effects. CPFE: Country-Pair Fixed Effects. PPML: } \\
\text { Poisson pseudo-maximum likelihood. CCI: Control of Corruption Index. The Hausman test result for } \\
\text { random effects vs fixed effects is } 2974.71(0.00) \\
\text { Source: Self made }\end{array}$} & $\begin{array}{l}\text { Table IV. } \\
\text { Estimations of the } \\
\text { impact of corruption } \\
\text { on trade with the } \\
\text { control of corruption } \\
\text { index }\end{array}$ \\
\hline
\end{tabular}

now on differences in corruption levels between partners, we find the expected negative and significant coefficient for CCI (at 10 per cent level) and SCI (at 1 per cent level), while a nonsignificant coefficient (although negative) is found for CPI. This implies a maximum trade loss for distinct degrees of corruption of around 10 per cent using CCI and 30 per cent using SCI.

The next step is to econometrically exploit the panel data nature of our samples. As it is well known, there are two basic methods to do this: random effects and fixed effects. Random effects assume that individual effects are uncorrelated with the regressors whereas fixed effects assume that they are. The Hausman test allows us to discriminate between both to select the unbiased and more efficient estimator. In the three samples, the Hausman test rejects the null of equal coefficients which implies that fixed effects is the preferred specification, as it is usual in trade gravity models. As explained, CPFE control for unobserved bilateral heterogeneity. This fact has no consequences on the estimated parameters of the variables of interest for the CPI. In the case of the CCI, the parameter of the difference in bilateral corruption level losses its statistical significance. However, the major change occurs with the SCI. Now, the estimated parameter for the average corruption in the pair is positive and significant at 1 per cent level implying that corruption boosts trade. This suggests that the parameter estimated in column 1 of Table $V$ is biased. With respect to the coefficient for differences in corruption levels, it remains negative and highly significant.

In Columns 3 and 4 of the mentioned tables, we finally control for multilateral resistance terms varying over time. The difference between Column 3 and 4 is that, in the specification 


\begin{tabular}{|c|c|c|c|c|c|}
\hline $\begin{array}{l}\text { AEA } \\
27,79\end{array}$ & Variables & $\begin{array}{c}(1) \\
\text { Pooled OLS }\end{array}$ & $\begin{array}{c}(2) \\
\text { Fixed effects }\end{array}$ & $\begin{array}{c}\text { (3) } \\
\text { OLS CYFE and CPFE }\end{array}$ & $\begin{array}{c}\text { (4) } \\
\text { PPML CYFE and CPFE }\end{array}$ \\
\hline \multirow{19}{*}{12} & $\ln Y_{i}$ & $1.003(0.012) * * *$ & $0.704(0.043)^{* * * *}$ & - & - \\
\hline & $\ln Y_{j}$ & $0.814(0.011)^{* * * *}$ & $0.738(0.042)^{* * * *}$ & - & - \\
\hline & lndist & $-0.967(0.032)^{* * *}$ & - & - & - \\
\hline & contiguity & $0.790(0.128)^{* * * *}$ & - & - & - \\
\hline & comlang & $0.472(0.063)^{* * * *}$ & - & - & - \\
\hline & colony & $1.045(0.106)^{* * * *}$ & - & - & - \\
\hline & comctry & $3.555(0.158)^{* * * *}$ & - & - & - \\
\hline & island & $0.374(0.157)^{* * *}$ & - & - & - \\
\hline & landlocked & $-0.520(0.050) * * * *$ & - & - & - \\
\hline & religion & $-0.233(0.078) * * *$ & - & - & - \\
\hline & RTA & $0.373(0.075) * * *$ & $0.172(0.089) * *$ & $0.279(0.086) * * * *$ & $0.330(0.054) * * * *$ \\
\hline & $\mathrm{CU}$ & $1.159(0.273)^{* * * *}$ & $-0.237(0.356)$ & $-0.001(0.340)$ & $0.251(0.095)^{* * *}$ \\
\hline & $\mathrm{SCI}_{\mathrm{ij}}$ & $-1.247(0.144)^{* * * *}$ & $1.153(0.202) * * *$ & $4.691(1.231)^{* * *}$ & $1.029(0.480) * *$ \\
\hline & $\mathrm{SCI}_{\mathrm{i}} \mathrm{SCI}_{\mathrm{j}}$ & $-0.292(0.114)^{* * * *}$ & $-0.601(0.177) * * *$ & $-0.233(0.259)$ & $-0.488(0.168)$ **** \\
\hline & Time dummies & Yes & Yes & No & No \\
\hline & CPFE & No & Yes & Yes & Yes \\
\hline & CYFE & No & No & Yes & Yes \\
\hline & $\mathrm{R}^{2}$ & 0.67 & 0.24 & 0.37 & 0.99 \\
\hline & Observations & 15,863 & 15,863 & 16,579 & 19,178 \\
\hline
\end{tabular}

Table V.

Estimations of the impact of corruption on trade with the structural corruption index
Notes: Sample period: 1978, 1983, 1988 and 1994. Dependent variable: log of bilateral exports for Column (1) to (3) and bilateral exports in levels for Column (4). Robust standard errors (clustered by country-pairs) are in parentheses. "significant at $10 \%$; ${ }^{* *}$ significant at $5 \%,{ }^{* * * *}$ significant at $1 \%$. OLS: Ordinary Least Squares. CYFE: Country-Year Fixed Effects. CPFE: Country-Pair Fixed Effects. PPML: Poisson PseudoMaximum Likelihood. SCI: Structural Corruption Index. The Hausman test result for random effects vs fixed effects is $351.59(0.00)$

Source: Self made

used in the last column [equation (2)], we additionally account for zero trade flows[14] and heteroskedastic residuals with the PPML estimator. Therefore, the results of Column 4 are our preferred ones. To the best of our knowledge, this is the first paper that both estimates the impact of corruption on trade taking into account all the cited sources of potential biases and using the SCI index. The last comments about the impact of our corruption variables on trade remain valid for the $\mathrm{CCI}$ and $\mathrm{SCI}$ measures. In the first case, corruption negatively affects trade and has no impact for differences in corruption levels. In the second case, corruption and differences in corruption levels positively and negatively affect trade, respectively. However, both corruption variables have not any significant impact when using the CPI index[15][16].

At this point, it is worth noting the following. As before stated, a number of authors have suggested that perception-based indexes are inappropriate to adequately analyse the impact of corruption on economic variables. Although CPI and CCI measures have been extensively used in the economic literature as part of the dependent and independent variables in regressions, these indicators are ordinal in nature and then, some doubts arise about the reliability of the results obtained with them. For this reason, Dreher et al. (2007) make an effort to construct a corruption indicator with economic sense. Obviously, if this is the case, it is perfectly possible that this index "may also provide a different assessment of the likely impact of corruption to the one produced by perception-based indexes", in authors' words.

Focussing on the results obtained until now, we find a positive effect of corruption on trade when using SCI[17]. This surprising result (but not new using other measures of 
corruption and other dependent variables) is plausible under the "grease the wheels' hypothesis. However, this hypothesis make sense in countries with highly regulated markets, usually jointly with the existence of weak institutions. Therefore, it is important to analyse this point. Additionally, we have found a significant negative effect of bilateral corruption differences when using SCI (not for CPI and CCI). This is most likely the result of a much more exact measure of distance of corrupt activities across countries.[18]

From the above considerations, a quite interesting point is whether the described pattern depends on the level of income of countries. To this end, we have decomposed the corruption variable in all the possible combinations by income (high, middle and low) and direction of trade (exporter and importer). The interpretation of the respective coefficients is direct. We present the estimations in Table VI. To clarify the information provided, let's consider two examples: The expression "Both High Income" means that the exporter and the importer are high income countries and the expression Exp_Minc_Imp_Linc means that the exporter is a middle income country whereas the importer is a low income one.

According to the results, we can extract three relevant conclusions. First, the absence of impact detected when using the CPI is generalised. In particular, we find just one (out of nine) parameter which is negative and significant (but only at 10 per cent level). Second, the negative effect of $\mathrm{CCI}$ is significant in five out of the nine combinations, not finding any particular behavioural pattern. For instance, corruption negatively affects trade between high income countries as well as between low income ones. Finally, it is observed that there are just three cases for which the SCI gives estimated coefficients which are positive and significant parameters that most likely drive the overall positive coefficient. These are high values and the two most relevant ones refer, on the one hand, to trade between low income countries and, on the other hand, to exports from low income countries to middle income countries[19]. That is precisely what we expected. As noted repeatedly along the text, corruption could positively impact economic variables when serves as a deregulation mechanism in highly regulated economies with poor institutional environment. This is the case of low income countries and a great part of middle income ones. Additionally, a much smaller (although significant) coefficient is found for exports from middle income countries to high income ones. Therefore, taking as a whole the results found for the SCI, we see that

\begin{tabular}{lccc}
\hline Variables & CPIij & CCIij & SCIij \\
\hline Both high income & $-0.068(0.065)$ & $-0.402(0.242)^{*}$ & $1.108(0.800)$ \\
Both medium income & $-0.138(0.089)$ & $-0.355(0.377)$ & $-0.202(1.345)$ \\
Both low income & $-0.155(0.190)$ & $-2.277(0.582)^{* * * *}$ & $9.358(2.424)^{* * * *}$ \\
Exp_Hinc_Imp_Minc & $-0.130(0.073)^{*}$ & $-0.732(0.275)^{* * * *}$ & $0.792(0.602)$ \\
Exp_Hinc_Imp_Linc & $-0.161(0.105)$ & $-0.639(0.335)^{*}$ & $0.263(0.674)$ \\
Exp_Minc_Imp_Hinc & $-0.005(0.080)$ & $-0.446(0.305)$ & $1.462(0.591)^{* * *}$ \\
Exp_Minc_Imp_Linc & $-0.178(0.122)$ & $-0.648(0.469)$ & $0.987(2.950)$ \\
Exp_Linc_Imp_Hinc & $-0.118(0.119)$ & $-0.604(0.402)$ & $0.419(0.876)$ \\
Exp_Linc_Imp_Minc & $-0.231(0.157)$ & $-1.104(0.554)^{* * *}$ & $6.460(1.953)^{* * * *}$ \\
Dif.corruption level & $0.005(0.009)$ & $0.017(0.024)$ & $-0.619(0.218)^{* * *}$ \\
$R^{2}$ & 0.99 & 0.99 & 0.99 \\
Observations & 185,529 & 221,068 & 19,178
\end{tabular}

Notes: Estimations are PPML CPFE and CYFE. Only variables related to corruption are presented. Exp: Exporter. Imp: Importer. Hinc: High income. Minc: Middle income. Linc: Low income; *significant at 10\%; ***significant at $5 \%$, ****significant at $1 \%$

Source: Self made
Corruption and international trade

13

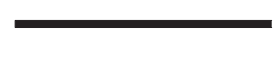


AEA 27,79

\section{4}

asymmetries in corruption have a clear negative effect which is compensated when trade takes place in the particular cases mentioned above.

Finally, we are interested in knowing if membership in RTA has any consequence on the relationship between corruption and trade. In principle, a given level of corruption may have less harmful effects in more transparent and predictable markets. To see this, we have added an additional dimension in our corruption variables decomposition: the fact that the pair of countries are part or not of an RTA. The results are in Table VII. As before, the interpretation of the coefficients is direct.

In the major part of cases there is not any substantial difference in the estimated impact of corruption on trade when distinguishing by RTA membership in any of the indexes considered. When this is not the case, and there is a statistical significant difference in the estimated coefficients, we do not find any particular behavior to extract robust conclusions. Therefore, it seems that RTA's membership does not change the relationship between corruption and trade.

\section{Conclusions}

From a theoretical point of view, the effects of corruption on international trade flows are ambiguous. On the one hand, corruption may act as a barrier to trade increasing the cost of doing international business. On the other hand, corrupt agents may facilitate trade in countries with strict regulations ("grease the wheels" hypothesis). To determine which factor dominates and in which circumstances is an empirical matter. In this paper, we have used three different measures of corruption to address this issue. Two of them, the

\begin{tabular}{lccc}
\hline Variables & CPIij & CCIij & SClij \\
\hline Both high income in RTA & $-0.066(0.065)$ & $-0.443(0.244)^{*}$ & $0.924(0.827)$ \\
Both high income not in RTA & $-0.083(0.065)$ & $-0.432(0.241)^{*}$ & $0.790(0.794)$ \\
Both medium income in RTA & $-0.149(0.089)^{*}$ & $-0.494(0.377)$ & $-0.973(1.340)$ \\
Both medium income not in RTA & $-0.125(0.090)$ & $-0.367(0.375)$ & $-0.732(1.322)$ \\
Both low income in RTA & $-0.110(0.186)$ & $-2.385(0.586)^{* * * *}$ & $9.131(2.527)^{* * *}$ \\
Both low income not in RTA & $-0.738(0.078)$ & $-1.291(0.629)^{* * *}$ & $9.456(2.690)^{* * * *}$ \\
Exp_Hinc_Imp_Minc in RTA & $-0.132(0.073)^{*}$ & $-0.794(0.277)^{* * * *}$ & $0.121(0.614)$ \\
Exp_HincImp_Minc not in RTA & $-0.151(0.072)^{* *}$ & $-0.751(0.277)^{* * * *}$ & $0.745(0.585)$ \\
Exp_Hinc_Imp_Linc in RTA & $-0.094(0.109)$ & $-0.631(0.368)^{*}$ & - \\
Exp_Hinc_Imp_Linc not in RTA & $-0.139(0.101)$ & $-0.671(0.333)^{* * *}$ & $0.086(0.661)$ \\
Exp_Minc_Imp_Hinc in RTA & $-0.005(0.080)$ & $-0.509(0.306)^{*}$ & $1.349(0.671)^{* *}$ \\
Exp_Minc_Imp_Hinc not in RTA & $-0.018(0.080)$ & $-0.467(0.303)$ & $1.271(0.581)^{* *}$ \\
Exp_Minc_Imp_Linc in RTA & $-0.062(0.123)$ & $-0.696(0.473)$ & $0.582(2.868)$ \\
Exp_Minc_Imp_Linc not in RTA & $-0.271(0.123)^{* * *}$ & $-0.657(0.466)$ & $0.579(3.177)$ \\
Exp_Linc_Imp_Hinc in RTA & $-0.186(0.167)$ & $-0.870(0.511)^{*}$ & - \\
Exp_Linc_Imp_Hinc not in RTA & $-0.100(0.118)$ & $-0.623(0.399)$ & $0.225(0.872)$ \\
Exp_Linc_Imp_Minc in RTA & $-0.057(0.174)$ & $-0.883(0.585)$ & $7.677(2.298)^{* * *}$ \\
Exp_LincImp_Minc not in RTA & $-0.343(0.159)^{* * *}$ & $-1.287(0.539)^{* * * *}$ & $5.073(1.969)^{* * * *}$ \\
Dif. corruption level & $0.006(0.009)$ & $0.021(0.024)$ & $-0.665(0.205)^{* * * *}$ \\
$R^{2}$ & 0.99 & 0.99 & 0.99 \\
Observations & 185,529 & 221,068 & 19,168
\end{tabular}

Table VII.
Estimations of the impact of corruption on trade by countries' income level and membership in RTA
Notes: Estimations are PPML CPFE and CYFE. Only variables related to corruption are presented. Exp: Exporter. Imp: Importer. Hinc: High income. Minc: Middle income. Linc: Low income. RTA: Regional Trade Agreement. In the case of the SCI index there is not any pair composed by a high income country and a low income one that form a RTA; *significant at 10\%; **significant at $5 \%$, *** significant at $1 \%$

Source: Self made 
Corruption Perception Index (CPI) and the Control of Corruption index (CCI), belong to the known as perception-based indexes. The third, that we called structural corruption index (SCI), constructed by Dreher et al. (2007), comes from a structural modelling which takes into account causes and indicators of corruption. This last index tries to overcome the relevant shortcomings of the indexes based on perceptions, as pointed out by several authors.

Our methodology relies on the estimation of gravity equations over wide samples taking into account the last methodological advances as well as a very recent estimation procedure to overcome convergence issues. According to the parameters estimated by this way (after

Corruption and international trade showing estimation with diverse sources of bias, previously employed in the literature) the results show a negative effect of corruption on trade when using CCI. However, a positive effect is found when using SCI. This last result is qualified when we take into account the income level of countries (high, middle or low). We show that the overall positive coefficient is mainly due to trade across low and middle income countries, that is, those with higher regulations and poor institutions. This is the case described by the "grease the wheels" hypothesis. Additionally, using the SCI, we show that differences in corruption levels negatively impact international trade, which is also in line with expectations. Finally, it does not seem that membership in RTAs had any influence in the relationship corruption-trade in any of the three indicators considered.

\section{Notes}

1. The first authors to apply gravity equations to trade flows were Tinbergen (1962) and Pöyhönen (1963), although lacking a theoretical basis. Anderson (1979) first provided the theoretical background. Subsequent developments came from Bergstrand (1985, 1989), Deardoff (1998), Evenett and Keller (2002), Anderson and van Wincoop (2003) or Helpman et al. (2008), among others.

2. The index is defined as: ( $\%$ Protestants in country $i * \%$ Protestants in country $j)+(\%$ Catholics in country $i * \%$ Catholics in country $j)+(\%$ Muslims in Country $i * \%$ Muslims in country $j)$.

3. This is because the existence of non-observable firm heterogeneity and fixed trade costs in line with the so-called new-new trade theory (Melitz, 2003).

4. Most of the aforementioned studies incorporates into the regression country-specific variables (for the exporter and the importer). However, these variables are perfectly collinear with countryyear fixed effects. Therefore, to investigate the effect of corruption on trade, it is necessary to construct country-pair variables.

5. Previously, we have made an adjustment to the CCI and SCI variables in order to avoid negative values.

6. It is important to note that there are no multicollinearity issues between both variables of corruption.

7. We are grateful to an anonymous referee for this point.

8. Obviously, we have used the same scale for all the period. Additionally, making estimations just till 2011 (in 2012 changes the scale), we do not find that results change in any significant way. We are grateful to an anonymous referee for this point.

9. For the last year available (2017), Transparency International finds an average score of 43 (4.3 in our scale), a value which is considered as a "poor performance".

10. High income encompasses OECD and non-OECD countries and Middle income encapsulates Upper Middle and Lower Middle. See http://data.worldbank.org/country.

11. The lower percentages observed in the case of $\mathrm{SCI}$ are the result of the period available for this index: RTAs have proliferated since the mid-1990s. 


\section{AEA}

27,79

\section{6}

12. The variable "religion" has a significant counterintuitive sign in all three cases. However, as it is well-known the OLS estimation is biased.

13. The maximum and minimum values of $\mathrm{CPI}_{\mathrm{ij}}$ for 2012 are -1.3 and -9 , respectively. Therefore, the calculation made is $\left[\exp \left(-0.14^{*}-9\right)-\exp \left(-0.14^{*}-1.3\right] / \exp \left(\left(-0.14^{*}-9\right)\right.\right.$. We have followed the same procedure for the other indexes.

14. The number of zeros represents $12.7 \%$ of the sample for CPI, $19.1 \%$ of the sample of CCI and $13.5 \%$ of the sample for SCI.

15. Note that this loss of significance also occurs with RTA and CU for the CPI and CCI samples. This is a usual recent result when using PPML with CYFE and CPFE in large samples and it has surprised the Academia which is now doing more research in the area.

16. We have not detected nonlinearities making estimations with the square of our corruption measures.

17. Dreher and Scheneider (2010) also find a discrepancy in the results obtained between the structural index and perception-based indexes when analysing the relationship between corruption and the extent of shadow economy.

18. We have made estimations with CPI and CCI using the same sample of countries as with SCI (see Appendix) and results do not change in a significant way. In particular, we find a non-significant impact of corruption on trade for CPI (a coefficient of -0.006 with a standard error of 0.077 ) and a negative and significant impact for CCI (a coefficient of -0.729 with a standard error of 0.233 ). Additionally, it would be quite interesting to know if the different results obtained are consequence of the distinct periods covered by the three indexes. However, there is only one overlapping year for the three cases considered (1996) implying a cross-section estimation and, therefore, with an outcome not directly comparable with the performed estimations. We are grateful to an anonymous referee for this point.

19. To give an idea of the positive impact of corruption on trade between low income countries just to say that an increase in one standard deviation in average corruption (0.066 in the sample of low income countries) implies $78 \%$ more trade. It is also important to note that these are really poor countries (see the Appendix list) and that they represent only 550 observations.

\section{References}

Acemoglu, A. and Verdier, T. (2000), "The choice between market failures and corruption", American Economic Review, Vol. 90 No. 1, pp. 194-211.

Akbarian, R. and Shirazi, H. (2012), "The effect of corruption on trade volumes of selected countries in the Middle east and Latin America (2002-2008)", Quarterly Journal of Quantitative Economics, Vol. 8, pp. 29-46.

Anderson, J. and Marcouiller, D. (2002), "Insecurity and the pattern of trade: an empirical investigation", Review of Economics and Statistics, Vol. 84 No. 2, pp. 342-352.

Anderson, J.E. (1979), “A theoretical foundation to the gravity equation”, American Economic Review, Vol. 69, pp. 106-116.

Anderson, J.E. and van Wincoop, E. (2003), "Gravity with gravitas: a solution to the border puzzle", American Economic Review, Vol. 93 No. 1, pp. 170-192.

Baier, S.L. and Berstrand, J.H. (2007), "Do free trade agreements actually increase members" international trade?", Journal of International Economics, No. 71, pp. 72-95.

Bergstrand, J.H. (1985), "The gravity equation in international trade: some microeconomic foundations and empirical evidence", The Review of Economics and Statistics, Vol. 67 No. 3, pp. 474-481. 
Bergstrand, J.H. (1989), "The generalised gravity equation, monopolistic competition, and the factor proportions theory in international trade", The Review of Economics and Statistics, Vol. 71 No. 1, pp. 143-153.

De Jong, E. and Bogmans, C. (2011), "Does corruption discourage international trade?", European

Corruption and international trade Journal of Political Economy, Vol. 27 No. 2, pp. 385-398.

Deardoff, A.V. (1998), "Determinants of bilateral trade: does gravity work in a neoclassic world?”, in Frankel, J. (Ed.), The Regionalization of the World Economy, University of Chicago Press, Chicago.

Dreher, A. and Gassebner, M. (2013), "Greasing the wheels? The impact of regulations and corruption on firm entry”, Public Choice, Vol. 155 Nos 3/4, pp. 413-432.

Dreher, A. and Schneider, M. (2010), "Corruption and the shadow economy: an empirical analysis", Public Choice, No. 144, pp. 215-238.

Dreher, A., Kotsogiannis, C. and McCorriston, S. (2007), "Corruption around the world: evidence from a structural model", Journal of Comparative Economics, Vol. 35 No. 3, pp. 443-466.

Dutt, P. and Traca, D. (2010), "Corruption and bilateral trade flows: extortion or evasion?", Review of Economics and Statistics, Vol. 92 No. 4, pp. 843-860.

Egger, P. (2002), "An econometric view on the estimation of gravity models and the calculation of trade potentials", The World Economy, Vol. 25 No. 2, pp. 297-312.

Egger, P. and Winner, H. (2005), "Evidence on corruption as an incentive for foreign direct investment", European Journal of Political Economy, Vol. 21 No. 4, pp. 932-952.

Evenett, S.J. and Keller, W. (2002), "On theories explaining the success of the gravity equation”, Journal of Political Economy, Vol. 110 No. 2, pp. 281-316.

Gil-Pareja, S., Llorca-Vivero, R. and Martínez-Serrano, J.A. (2008a), “Assessing the enlargement and deepening of the European union”, World Economy, Vol. 31, pp. 1253-1272.

Gil-Pareja, S., Llorca-Vivero, R. and Martínez-Serrano, J.A. (2008b), "Trade effects of monetary unions: evidence from OECD countries", European Economic Review, Vol. 52 No. 4, pp. 733-755.

Gil-Pareja, S., Llorca-Vivero, R. and Martínez-Serrano, J.A. (2017), "The effect of nonreciprocal preferential trade agreements on benefactors" exports", Empirical Economics, Vol. 52 No. 1, pp. 143-154.

Helpman, E., Melitz, M. and Rubinstein, Y. (2008), " "Estimating trade flows: trade partners and trade volumes", Quarterly Journal of Economics, Vol. 123 No. 2, pp. 441-487.

Horsewood, N. and Voicu, A.M. (2012), "Does corruption hinder trade for the new EU members", Economics: The Open-Access, Open-Assessment E-Journal, Vol. 6, pp. 1-28.

Klein, M.W. and Shambaugh, J.C. (2006), "Fixed exchange rates and trade", Journal of International Economics, Vol. 70 No. 2, pp. 359-383.

Knack, S. and Azfar, O. (2003), "Trade intensity, country size and corruption", Economics of Governance, Vol. 4 No. 1, pp. 1-18.

Larch, M., Wanner, J., Yotov, Y. and Zylkin, T. (2017), "The currency union effect: a PPML reassessment with high-dimensional fixed effects", Drexel University Working Paper 2017-07.

Levchenko, A. (2007), "Institutional quality and international trade", The Review of Economic Studies, Vol. 74 No. 3, pp. 791-819.

Masila, J.W. and Sigue, S.P. (2010), "Corruption and international trade: an empirical investigation of African countries", The World Economy, Vol. 33 No. 1, pp. 129-146.

Masson, P.R. and Patillo, C. (2005), The Monetary Geography of Africa, Brookings Institution Press, Washington.

Mauro, P. (1995), "Corruption and growth", The Quarterly Journal of Economics, Vol. 110 No. 3, pp. 681-712. 
Mauro, P. (1998), "Corruption and the composition of government expenditure", Journal of Public Economics, Vol. 69 No. 2, pp. 263-279.

Melitz, M.J. (2003), "The impact of trade on intra-industry reallocations and aggregate industry productivity", Econometrica, Vol. 71 No. 6, pp. 1695-1725.

Méon, P.G. and Weill, L. (2010), "Is corruption an efficient grease?", World Development No. 38, pp. 244-259.

Mocan, N. (2008), "What determines corruption? International evidence from microdata", Economic Inquiry, Vol. 46 No. 4, pp. 493-510.

Pomfret, R. and Sourdin, P. (2010), "Why do trade costs vary?", Review of World Economics, Vol. 146 No. 4, pp. 709-730.

Pöyhönen, P. (1963), "A tentative model for the volume of trade between countries”, Weltwirtschaftliches Arhiv, Vol. 90, pp. 92-100.

Reinhart, C.M. and Rogoff, K.S. (2002), "The modern history of exchange rates arrangements: a reinterpretation”, The Quarterly Journal of Economics, Vol. 119, pp. 1-48.

Razafindrakoto, M. and Rouboud, F. (2010), "Are international databases on corruption reliable? A comparison of expert opinion surveys and household surveys in sub-Saharan Africa", World Development, Vol. 38 No. 8, pp. 1057-1069.

Santos Silva, J.M.C. and Tenreyro, S. (2006), "The log of gravity", Review of Economics and Statistics, Vol. 88 No. 4, pp. 641-658.

Santos Silva, J.M.C. and Tenreyro, S. (2010), "On the existence of the maximum likelihood estimates in Poisson regression”, Economics Letters, Vol. 107 No. 2, pp. 310-312.

Thede, S. and Gustafson, N. (2009), "The multifaceted impact of corruption on international trade", International Trade Working Papers, Lund University.

Tinbergen, J. (1962), Shaping the World Economy, Twentieth Century Fund, New York, NY.

Voraveeravong, P. (2013), "Corruption impacts on bilateral trade between ASEAN countries during 2006 to 2011: gravity model approach”, World Journal of Social Sciences, Vol. 3, pp. 27-44.

Weber Abramo, C. (2008), "How much do perceptions of corruption really tell Us?", Economics: The Open-Access, Open-Assessment E-Journal, Vol. 2 No. 3, pp. 1-56.

Wei, S. (2000), "How taxing is corruption on international investors", Review of Economics and Statistics, Vol. 82 No. 1, pp. 1-11.

Zelekha, Y. and Sharabi, E. (2012), "Corruptions, institutions and trade", Economics of Governance, Vol. 13 No. 2, pp. 169-192.

\section{Further reading}

Wooldridge, J. (2010), Econometric Analysis of Cross Section and Panel Data, 2nd ed., The MIT Press, Cambridge, MA. 
Appendix

Corruption and international trade

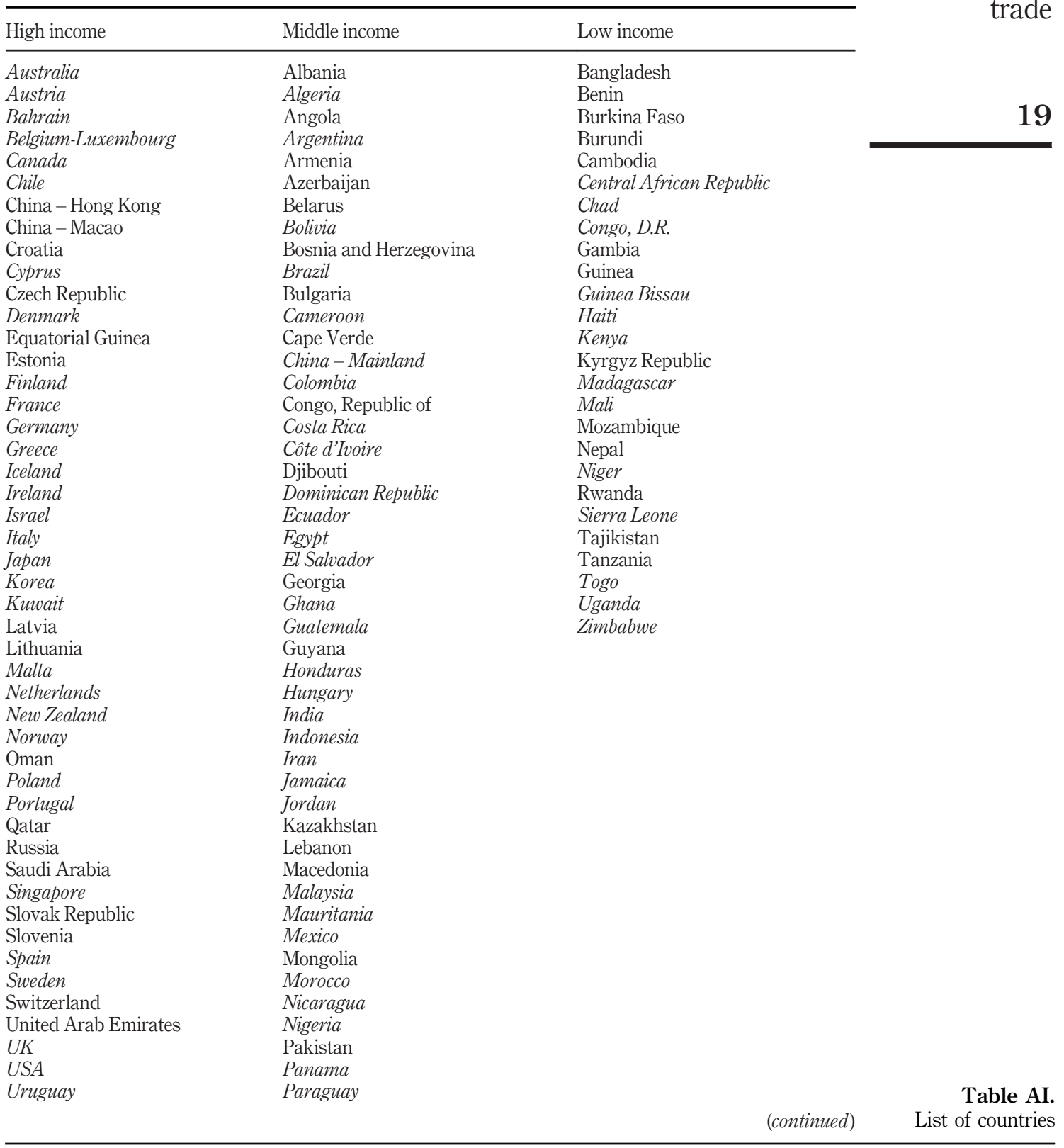


AEA

27,79

20

\begin{tabular}{ll} 
High income & Middle income \\
\hline Peru & Low income \\
\hline Philippines & Romania \\
Senegal & Serbia and Montenegro \\
South Africa & Sri Lanka \\
St. Tome and Principe & Sudan \\
Swaziland & Syria \\
Thailand & Tonga \\
Tunisia & Turkey \\
Ukraine & Venezuela \\
Vietnam \\
Yemen \\
Zambia
\end{tabular}

Table AI.

Notes: In italics, the list of countries used in the estimations with the SCI measure. Countries have been selected in each group of income following the World Bank classification

\section{Corresponding author}

Rafael Llorca-Vivero can be contacted at: rafael.1lorca@uv.es

For instructions on how to order reprints of this article, please visit our website: www.emeraldgrouppublishing.com/licensing/reprints.htm

Or contact us for further details: permissions@emeraldinsight.com 